\title{
Specjalne i nie-specjalne. Dylematy współczesnego podejścia do potrzeb osób z niepełnosprawnością
}

\begin{abstract}
Dorota Podgórska-Jachnik, Specjalne i nie-specjalne. Dylematy wspótczesnego podejścia do potrzeb osób z niepetnosprawnościa [Special and non-special. Dilemmas of a modern approach to the needs of people with disabilities]. Interdyscyplinarne Konteksty Pedagogiki Specjalnej, nr 21, Poznań 2018. Pp. 67-86. Adam Mickiewicz University Press. ISSN 2300-391X. DOI: https:// doi.org/10.14746/ikps.2018.21.04

The article is devoted to the problems of disability seen through the prism of needs, both those referred to as special (special educational, developmental, professional needs), as well as those universal. The term (special) needs were analyzed, in particular the problem of losing its basic, psychological significance in the special pedagogy of recent years, as well as its theoretical and practical explorations in relation to nursing-compensating, educational and therapeutic activities. Text points attention to the need to update analyzes consistent with the idea of inclusion, in relation to the issue of the needs of people with disabilities, as a motivating factor and compensation area.
\end{abstract}

KEY WORDS: special needs, unmet needs, disability, inclusion

\section{Wprowadzenie}

Pojęcie "specjalne potrzeby" stało się obecnie jednym z terminów najintensywniej używanych w pedagogice specjalnej. Badający percepcję społeczną tego pojęcia Morton A. Gernsbacher i wsp. 
wskazują, iż obecnie Google Scholar indeksuje ponad milion artykułów naukowych z tym określeniem, a Amazon.com sprzedaje prawie 5000 książek, które zawierają je w tytule ${ }^{1}$. Choć powszechnie znana jest jego historia i uwarunkowania jego pojawienia się, bywa coraz rzadziej użytkowane w zgodzie ze swoim źródłowym znaczeniem: najczęściej traktowane jest jako etykieta będąca współczesnym synonimem niepełnosprawności, a niestety rzadko jako indeks wskazujący na zawartą w nim psychologiczną kategorię potrzeby. Pojawia się ryzyko, że wypowiadając tysiące razy słowo "potrzeby", można osiągnąć efekt habituacji i przestać dostrzegać za nim osobę, która takie czy inne potrzeby przejawia. Tymczasem to w racjonalności odpowiedzi na potrzeby osób z niepełnosprawnością leży sedno ich efektywnego wspierania i społecznej inkluzji.

\section{Specjalne potrzeby - eufemizm pojęcia niepełnosprawność, czy faktyczne pytanie o potrzeby osoby?}

Wiedza o niepełnosprawności - jej przyczynach, uwarunkowaniach, wynikających z niej ograniczeniach, ale także możliwościach przeciwdziałania jej oraz minimalizowania jej skutków - zmieniała się przez wieki. Wraz z rozwojem nauk, zwłaszcza medycyny, zwiększała się zdolność wyjaśniania tajemnicy niepełnosprawności, ale również zmieniało się zainteresowanie nią społeczeństwa oraz przejawiane przez to społeczeństwo postawy wobec osób niepełnosprawnych. Obecnie niepełnosprawność jest traktowana jako złożone zjawisko wpisane w ludzkie losy i kształtujące (determinujące) te losy, dlatego poświęca się jej nie tylko wiele opracowań medycznych, ale również coraz więcej refleksji natury humanistycznej, filozoficznej, pedagogicznej i psychologicznej. Skutkiem tego jest pojawienie się $\mathrm{w}$ nauce różnych koncepcji teoretycznych i kategorii

1 M.A. Gernsbacher, et al., "Special needs" is an ineffective euphemism, Cognitive Researche No 1(1): 292016 (źródło: https://doi.org/10.1186/s41235-016-0025-4 [Pub. Online 2016 Dec 19], [dostęp: 15.01.2018]. 
objaśniających fenomen niepełnosprawności. Do takich można zaliczyć postrzeganie niepełnosprawności poprzez pryzmat wynikających z niej specjalnych potrzeb człowieka.

Z punktu widzenia psychologii potrzeby lokalizowane są wśród czynników motywujących i dynamizujących ludzkie działania, natomiast stanowią one coś więcej niż kierujące człowiekiem instynkty i popędy. Najkrótsza definicja potrzeby (ang. need) określa ją jako stan niezaspokojenia², choć można mówić zarówno o konieczności (nieodpartej) wykonania czegoś, jak również o instrumentalnym braku czegoś do osiągnięcia, pewnego oczekiwanego stanu, celu, zamiaru. Wśród tłumaczeń i synonimów znajdują się jednak również takie określenia, jak: trudności, bieda, ubóstwo, niedostatek, trudne położenie. Wszystko to razem wskazuje, iż mamy do czynienia z silnym i zróżnicowanym przedmiotowo regulatorem ludzkiego zachowania, często o charakterze imperatywu, nieodpartego bodźca.

Pojęcie "specjalne potrzeby" kojarzy się przede wszystkim z pojęciem „specjalne potrzeby edukacyjne", które zostało wprowadzone 40 lat temu przez Mary Warnock jako alternatywa dla prostej dychotomizacji: „niepełnosprawność” - „nie-niepełnosprawność” oraz odpowiadającej im prostej dychotomizacji wyborów edukacyjnych w praktyce oświatowej: szkoła specjalna - zwykła szkoła. Dostrzeżenie złożoności indywidualnych potrzeb wszystkich uczniów - nie tylko tych z niepełnosprawnością - spowodowało myślenie kategoriami niezbędnej, zróżnicowanej pomocy, uwzględniającej nie tylko niepełnosprawność, ale wszystkie czynniki, które mają wpływ na edukacyjne postępy jednostki³. Można to określić mianem podejścia pozytywnego, które odzwierciedla następujący sposób myślenia: nie ważne, z czego wynikaja i czym sa twoje ograniczenia, istotne jest, czego szczególnego potrzebujesz, by mimo nich osiągá standardy takie jak inni. Było to zatem przejście od medycznej kategoryzacji uczniów oraz

2 S.C. Rathus, Psychologia wspótczesna, Wydawnictwo GWP, Gdańsk 2005, s. 442.

${ }^{3}$ The Warnock Report, Special Educational Needs. Report of the Committee of Enquiry into the Education of Handicapped Children and Young People, Her Majesty's Stationery Office, London 1987. 
etykiety diagnozowanych $\mathrm{u}$ nich deficytów do funkcjonalnego rozumienia ich potrzeb. Warnock rozumiała przy tym potrzebę $\mathrm{w}$ szerokich kategoriach edukacyjnych jako konieczność zastosowania jednej z lub kilku z następujących form kompensacyjnych działań szkoły:

- zapewnienia specjalnych środków dostępu do programu nauczania za pomocą specjalnego wyposażenia, urządzeń lub zasobów, modyfikacji środowiska fizycznego lub specjalistycznych technik nauczania,

- zapewnienia specjalnego lub zmodyfikowanego programu nauczania,

- zwrócenia szczególnej uwagi na strukturę społeczną i klimat emocjonalny, w którym odbywa się edukacja ${ }^{4}$.

Koncepcja Warnock, a przede wszystkim samo pojęcie specjalnych potrzeb, zrobiły na świecie zawrotną karierę. Gdy ćwierć wieku temu Ruth Luckasson i wsp. sformułowałi propozycję określenia stopni upośledzenia umysłowego zakresem niezbędnego wsparcia psychospołecznego, umocniło to $\mathrm{w}$ światowym dyskursie naukowym ideę praktycznej operacjonalizacji potrzeb wynikających z niepełnosprawności, co obecnie zaczyna być standardem. Potrzeby te w ujęciu Luckasson można stopniować (zamiast tradycyjnych stopni upośledzenia umysłowego): od sporadycznej pomocy przez pomoc ograniczoną, znaczną aż do całkowitej ${ }^{5}$.

Pojęcie specjalnych potrzeb (edukacyjnych) nie tylko zakorzeniło się $\mathrm{W}$ systemie pojęciowym pedagogiki specjalnej, ale także - nieco wbrew intencjom twórców - zaczęło zastępować pojęcie niepełno-

${ }^{4}$ Ibidem, s. 41 . W oryginale:

- the provision of special means of access to the curriculum through special equipment, facilities or resources, modification of the physical environment or specialist teaching techniques;

- the provision of a special or modified curriculum;

- particular attention to the social structure and emotional climate in which education takes place.

${ }^{5} \mathrm{R}$. Luckasson, et al., Mental retardation: Definition, classification, and systems of supports (9th ed.). Washington, DC: AAMR 1992. 
sprawności. Czy za jakiś czas stanie się ono kolejną etykietą o pejoratywnym wydźwięku? To bardzo prawdopodobne - M.A. Gernsbacher i współautorzy 6 wykazują empirycznie jego początkowo eufemistyczny charakter, a obecnie stopniowe przekształcanie się dysfemizm 7 . W interesującym eksperymencie atrybucyjnym, obejmującym badania na dużej grupie $\mathrm{N}=530$ osób, autorzy wykazali, iż pojęcie specjalnych potrzeb kojarzy się obecnie z większym stopniem negatywności i większym potencjałem stygmatyzacyjnym niż pojęcie niepełnosprawność, które postrzegane jest według badaczy "bardziej integracyjnie" . Autorzy, opierając się na swych odkryciach, wręcz nie zalecają używania określenia "specjalne potrzeby", co warto rozważyć w tych krajach, gdzie zdominowało ono dyskurs oświatowy, a więc także i w Polsce. Wskazują też kampanie lobbujące za usunięciem z mediów - w tym mediów społecznościowych zarówno określenia „specjalne”, jak i postrzeganego jako eufemizm pojęcia „specjalne potrzeby" 9 . Przywołują również postulaty Colina Barnesa, przedstawiciela współczesnych interdyscyplinarnych $\mathrm{Di}$ sability studies, apelującego, by zastąpić termin „kształcenie specjalne” - „edukacją włączającą”, "specjalne potrzeby edukacyjne” „niezaspokojonymi potrzebami edukacyjnymi”, a określenie „dzieci ze specjalnymi potrzeby edukacyjnymi" - ponownie nieeufemistycznym, a jednoznacznym terminem „dzieci niepełnosprawne” ${ }^{\prime 10}$.

Przyszłość pojęcia „specjalne potrzeby” wydaje się więc niepewna, tym bardziej, iż według Gernsbacher pojęcie to „wywołuje

${ }^{6}$ M.A. Gernsbacher i in., op. cit.

${ }^{7}$ Dysfemizm - odwrotność eufemizmu, zastąienie przyzwoitego, oględnego a. obojętnego stowa a. wyrażenia drażliwym, dosadnym a. nieprzyzwoitym. [online] http://www. slownik-online.pl/kopalinski/6912E60D67C51EA4412565BA002919B3.php [dostęp: 15.01.2018].

8 M.A. Gernsbacher i in., op. cit.

9 Vide: \#NoSpecial - Carter-Long, 2016; \#Don'tCallMeSpecial - Reeves, 2015 [za:] M.A. Gernsbacher i in., op. cit.

${ }^{10} \mathrm{C}$. Barnes, A. Sheldon, 'Emancipatory' disability research and special educational needs. [In:] Florian L, ed., The Sage handbook of special education, Sage, London 2007, s. 233-246. 
więcej pytań bez odpowiedzi"11, co prowokuje z kolei do identyfikacji tych pytań. Jednym z nich może być pytanie o to, jakie skutki teoretyczne i praktyczne wiążą się ze zbudowaniem omawianego pojęcia wokół psychologicznej kategorii „potrzeby”. Zanim więc uznamy za niepotrzebne i wyrzucimy etykiety "specjalnych potrzeb" czy "specjalnych potrzeb edukacyjnych" do śmietnika nauki, warto jednak wrócić do źródła i wyłuskać z tego złożonego pojęcia jedno kluczowe słowo, które zmieniło sposób patrzenia na osobę z niepełnosprawnością: samo psychologiczne pojęcie "potrzeby", oraz zastanowić się nad jego współczesnym sensem i wynikającymi stąd zobowiązaniami.

Drugim obszarem znaczeniowym, w którym pojawia się słowo "potrzeba" w odniesieniu do osób z niepełnosprawnością, są „potrzeby niezaspokojone" (ang. unmet needs). Choć jeszcze nieosadzone tak silnie $\mathrm{w}$ dyskursie pedagogiki specjalnej jak potrzeby specjalne (ang. special needs), pojęcie to zaczyna dominować w podejściu do problemów niepełnosprawności w polityce zdrowotnej i społecznej. Wpisuje się ono $\mathrm{w}$ podejście inkluzyjne, gdyż permanentny brak zaspokojenia pewnych potrzeb niektórych grup społecznych jest identyfikowany jako czynnik o charakterze wykluczającym, czemu współczesny ruch inkluzyjny - polityka zrównoważonego rozwoju, medycyna włączająca, edukacja włączająca, współczesna praca socjalna oparta na idei empowermentu - stara się przeciwdziałać12.

Uznanie osób z niepełnosprawnością za grupę wrażliwą, czyli zagrożoną marginalizacją i wykluczeniem jest powodem, dla którego podejmuje się diagnozę potrzeb i stopnia ich zaspokojenia. Przykładem takich działań na szczeblu międzynarodowym jest World report on disability WHO z 2011 r., gdzie kategoria "potrzeb i niezaspokojonych potrzeb" osób z niepełnosprawnością jest wyróżnioną częścią modelu analitycznego zastosowanego zarówno do ogólnej opieki zdrowotnej (ang. general health care) we wszystkich jej zakre-

11 Ibidem.

12 D. Podgórska-Jachnik, Praca socjalna z osobami z niepetnosprawnością I ich rodzinami, Centrum Rozwoju Zasobów Ludzkich MPiPS, Warszawa 2014. 
sach - promocji zdrowia, profilaktyki, podstawowej opieki medycznej i leczenia specjalistycznego, jak i rehabilitacji (ang. rehabilitation) oraz szeroko rozumianej opieki i wsparcia (ang. assistance and suport $)^{13}$. Tak rozległy zakres analiz związany jest z bio-psychospołecznym modelem niepełnosprawności oraz ideą holistycznego, funkcjonalnego podejścia do niepełnosprawności, wyrażonego najpełniej w koncepcji ICF - International Classification od Functioning, Disability and Health WHO. W efekcie tego badanie potrzeb i niezaspokojonych potrzeb ujęte $\mathrm{w}$ wymienionych trzech obszarach w przywoływanym Raporcie WHO podporządkowane jest idei inkluzji poprzez docelowe działania odpowiednio na rzecz:

- zmniejszenia nierówności w zakresie zdrowia oraz osiąganie najwyższych standardów zdrowotnych i funkcjonalnych osób z niepełnosprawnością,

- szeroko pojętej rehabilitacji, ukierunkowanej na osiągnięcie oraz utrzymanie optymalnego funkcjonowania $\mathrm{w}$ interakcji z otoczeniem mimo niepełnosprawności,

- wsparcia i opieki, umożliwiających optymalny poziom samodzielności i niezależnego życia ${ }^{14}$.

Przykładem ciekawych diagnoz przeprowadzonych dla celów polityki społecznej na szczeblu krajowym i lokalnym, uwzględniających potrzeby i niezaspokojone potrzeby osób z niepełnosprawnością, mogą być:

- ogólnopolski raport opracowany w 2017 roku na zlecenie Państwowego Funduszu Rehabilitacji Osób Niepełnosprawnych (PFRON); badania zrealizowano na grupie badawczej $\mathrm{N}=966$, dobranych według szczegółowego algorytmu opisanego w metodologii ${ }^{15}$,

13 World report on disability, World Health Organisation, The World Bank, Genewa 2011.

14 Ibidem.

${ }^{15}$ M. Sochańska-Kawiecka i wsp., Badanie potrzeb osób niepetnosprawnych - RAPORT KOŃCOWY; Badania Społeczne MSK, PFRON 2017, [online] https://www. pfron.org.pl/fileadmin/Badania_i_analizy/Badanie_potrzeb_ON/Raport_koncowy _badanie_potrzeb_ON.pdf [dostęp: 5.01.2018]. 
- raport z badania potrzeb i satysfakcji z wybranych usług społecznych, służących ich zaspokojeniu, dzieci z orzeczoną niepełnosprawnością i ich rodziców z województwa łódzkiego, przeprowadzonego w roku 2016 na zlecenie Regionalnego Centrum Polityki Społecznej (RCPS) w Łodzi; badania zrealizowano na reprezentatywnej losowej próbie $\mathrm{N}=322$ rodziców i $\mathrm{N}=359$ dzieci uczęszczających do 24 gimnazjów specjalnych i 24 szkół podstawowych specjalnych w województwie ${ }^{16}$.

Wszystkie trzy raporty - WHO, PFRON i RCPS w Łodzi - dostępne są $\mathrm{w}$ internecie i stanowią przykład narzędziu rzeczywistego kształtowania polityk różnego szczebla, umożliwiających zarządzanie niepełnosprawnością z punktu widzenia zdiagnozowanych potrzeb. Warto dodać, że nowoczesne podejście do tego problemu, zgodne z polityką społeczną empowermentu, wyraża się w postulacie planowania usług medycznych i socjalnych odpowiednich do zaspokojenia spersonalizowanych potrzeb (ang. need-based service), zamiast dopasowywania osoby z niepełnosprawnością do dostępnej usługi - bycia obsługiwanym (ang. being service-led) ${ }^{17}$. To wskazuje także, że diagnoza społeczna jest zawsze tylko pewnym tłem dla działań zindywidualizowanych na rzecz osób z niepełnosprawnością i że skutki działań wspierających należy rozpatrywać także a właściwie przede wszystkim - z uwzględnieniem psychologicznych mechanizmów uruchamianych przez wektory potrzeb i działań zmierzających do ich zaspokojenia. Można być bowiem odbiorcą wsparcia $\mathrm{w}$ roli podmiotu lub przedmiotu. $\mathrm{W}$ podmiotowym podejściu do potrzeb osób z niepełnosprawnością kryje się nie tylko ochrona przed nierównością, ale także potencjał kompensacyjny o charakterze rozwojowym. Wymaga to jednak głębszego wglądu specyfikę struktury potrzeb indywidualnych w sytuacji niepełno-

16 J. Pyżalski, D. Podgórska-Jachnik (red.), Badanie potrzeb i satysfakcji z wybranych ustug skierowanych do rodzin $z$ dziećmi $z$ orzeczona niepetnosprawnościa w wieku 8-16 lat. Raport z badań IMP na zlecenie RCPS w Łodzi 2016, [online] http:/ /www. imp.lodz.pl/upload/ aktualnosci/2016/raport.pdf [dostęp: 5.01.2018].

${ }^{17}$ J. Harris, H. Morgan, C. Glendinning et al., Personalised social care for adults with disabilities: a problematic concept for frontline practice. Health \& Social Care in the Community 2006, 14, s. 125-135. 
sprawności, z naciskiem na psychologiczne znaczenie pojęcia potrzeby, ale i jego interdyscyplinarne implikacje. W dalszej części opisana będzie praktyczna możliwość wykorzystania dwóch koncepcji teoretycznych przystających do analizowanego obszaru: koncepcja Dorothei Orem i polska koncepcja Kazimierza Obuchowskiego, z odniesieniami do koncepcji potrzeb Abrahama Maslowa - tu bliżej nie omawianej, ze względu na jej upowszechnienie.

\section{Specyfika potrzeb osób z niepełnosprawnością z perspektywy deficytu i rozwoju}

W psychologii wskazuje się na dwie podstawowe kategorie potrzeb: związane z brakiem (ang. deficiency needs) i związane $\mathrm{z}$ rozwojem (ang. growth needs). Stanowią one podstawę bardziej złożonych teoretycznych modeli klasyfikacji potrzeb, ale i empirycznych weryfikacji wzajemnych relacji między nimi ${ }^{18}$. Wtórną kwestią pozostaje to, jakie treści szczegółowe - w tym także jakie wartości - podkładane są pod pojęcia braku i rozwoju. W przypadku niepełnosprawności, gdzie ograniczenia i deficyty są szczególnymi warunkami kształtowania ludzkiego doświadczenia kategoria deficiency needs wydaje się szczególnie istotna. Deficyt wydaje się też podstawowym czynnikiem określającym szczególność/specjalność potrzeb osób z niepełnosprawnością. Przy tym nie chodzi o to, że osoby z niepełnosprawnością potrzebują czegoś więcej, tylko że mogą potrzebować tego bardziej, tzn. skutki niezaspokojenia tych potrzeb mogą stanowić poważne zagrożenie dla rozwoju, zdrowia lub życia. Specyfika potrzeb braku nie wiąże się też ze szczególnością niedoboru, ale ze szczególnością w zakresie możliwości jego wyrównania - zwłaszcza samodzielnego. Zatem można przyjąć, że także deficyt samodzielności sprawia, iż potrzeby osób z niepełnosprawnością określane są mianem specjalnych.

${ }^{18} \mathrm{~Np}$. A. Noltemeyer $\mathrm{i}$ in., The relationship among deficiency needs and growth needs: An empirical investigation of Maslow's theory, "Children and Youth Services Review", Vol. 34, Issue 9, September 2012, s. 1862-1867. 
Inspirującą koncepcją z punktu widzenia potrzeb osób z niepełnosprawnością widzianych przez pryzmat deficytu samodzielności, a więc i konieczności korzystania dla ich zaspokajania ze wsparcia społecznego, jest teoria samoopieki i jej deficytu (ang. Self Care Deficit Theory) Dorothei Orem ${ }^{19}$. Koncepcja ta stanowi jedną z klasycznych teorii pielęgniarstwa i podstawę jego modelu praktycznego ${ }^{20}$, jednak może być ona ciekawą inspiracją do oddzielenia tego, co w przypadku choroby lub niepełnosprawności stanowi aspekt medyczny i pozamedyczny. To istotny przyczynek do dyskusji nad realnością całkowitego odcięcia się od ujęcia medycznego w postulowanym obecnie społecznym modelu niepełnosprawności. Co więcej, jest to spojrzenie z perspektywy „uspołeczniającej się” medycyny. Widać to w modelu Orem w zasadzie samoograniczania kompensacyjnej interwencji pielęgniarskiej do niezbędnego minimum, wyznaczonego aktualnymi potrzebami osoby wspomaganej, na rzecz stopniowego włączania elementów edukacyjnych i aktywizujących posiadane, a ograniczone chorobą czy niepełnosprawnością zasoby samoopieki. To pewna analogia do tendencji samoograniczania się pedagogiki specjalnej w celu wyzwalania zasobów samodzielności i autonomii osoby z niepełnosprawnością.

Samoopieka jest formą samodzielności. Według Orem jest to umiejętność sprawowania opieki nad sobą i nad swoimi bliskimi, wynikająca z wrodzonej skłonności do samopielęgnowania. Samoopieka jest niezbędna dla zdrowia i życia, gdyż stanowi warunek (samodzielnego) zaspokajania własnych potrzeb, czego człowiek uczy się w ciągu życia, poszerzając swoją wiedzę i umiejętności. Jest zatem według Orem „świadomą, wyuczoną aktywnością ukierunkowaną na zaspokojenie określonych potrzeb, która w sposób celowy integruje funkcjonowanie i rozwój jednostki"21. Jednak w życiu człowieka zachodzą pewne zdarzenia powodujące deficyt samoopieki (ang. self care), do

19 D. Orem, Nursing: Concepts of practice, St. Louis, Mosby, MO 2001.

${ }^{20}$ A. Bigs, Orem's Self-Care Deficit Nursing Theory: Update on the State of the Art and Science, "Nursing Science Quarterly", Vol. 21, Issue: 3 2008, s. 200-206.

${ }^{21}$ G. Kowalik, Praktyczne zastosowanie modelu pielegnowania Dorothy Orem, "Studia Medyczne" 2012, 26(2), s. 108. 
których można zaliczyć równego rodzaju zmiany sytuacji osobistej, a więc można powiedzieć: kryzysy - w znaczeniu psychicznym, społecznym, ekonomicznym czy zdrowotnym (rys. 1).

Znaczenie tej koncepcji wydaje się szczególnie przystawać do problematyki niepełnosprawności, definiowanej poprzez ograniczenie samodzielności i zdolności do zaspokajania potrzeb. Może być też pomostem pomiędzy wspomnianą już diagnozą społeczną potrzeb osób z niepełnosprawnością dla celów polityki zdrowotnej i oświatowej (raport WHO) a spersonalizowaną, indywidualną strategią ich zaspokajania, sprzyjającą nie tylko wyrównywaniu różnic,

\section{POTRZEBY}

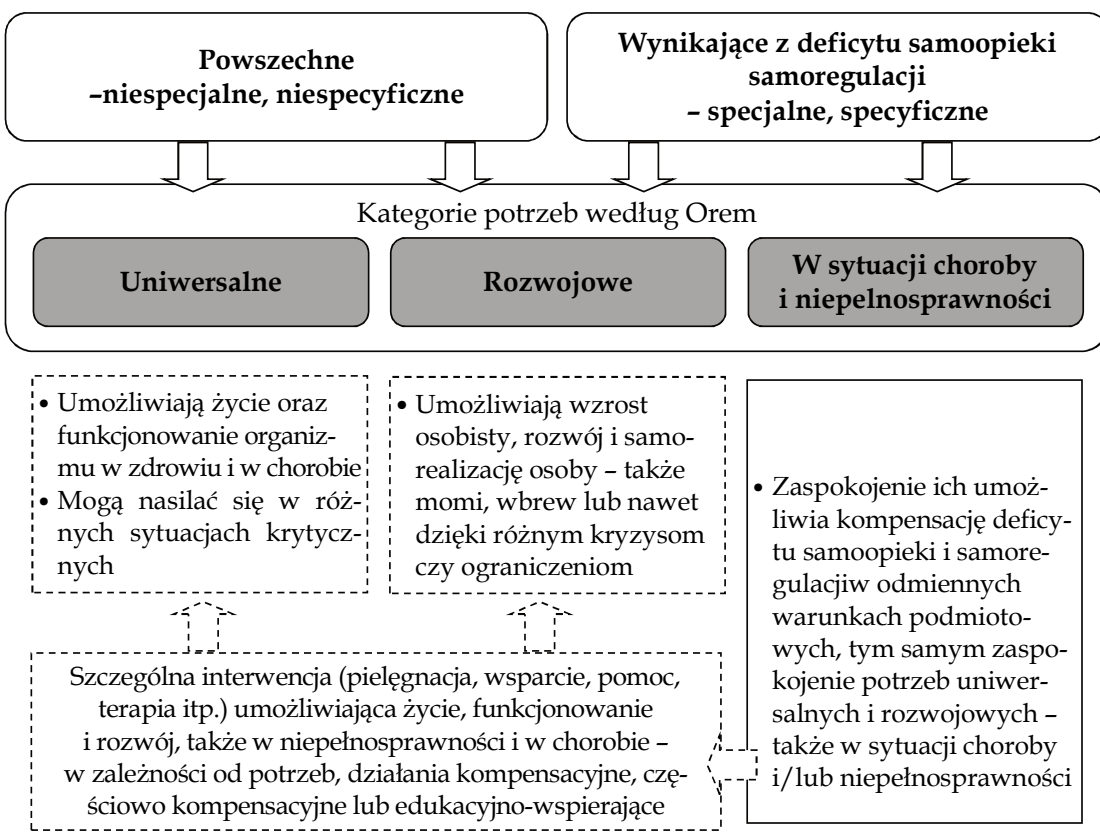

Rys. 1. Kategorie niespecyficznych i specyficznych (specjalnych) potrzeb człowieka w sytuacji choroby i niepełnosprawności jako próba uogólnienia modelu deficytu samoopieki (Self Care Deficit Theory) Dorothei Orem (źródło: opracowanie własne zmodyfikowanego modelu Orem) 
ale także wyzwalającą potencjał rozwojowy jednostki. Orem, koncentrując się na aspekcie zdrowotnym i problemie choroby, uzasadnienia swoją koncepcją potrzebę i charakter interwencji pielęgniarskiej, lecz wydaje się, że można ten model rozciągnąć na inne rodzaje niezbędnego wsparcia. W świetle podjętego tematu, najistotniejsze jest jednak wyróżnienie przez Orem trzech grup potrzeb, które dają się zauważyć w sytuacji choroby i/lub niepełnosprawności powodującej deficyt samoopieki. Są to potrzeby uniwersalne, rozwojowe i potrzeby ujawniające się $w$ zaburzeniach stanu zdrowia (rys. 1). Odpowiada to podejściu zainicjowanemu w latach 90. XX w. przez Denisa C. Harpera, które łączy aspekty medyczne choroby z psychologicznymi i społecznymi. Podział ten można dokładnie odnieść do sytuacji osoby z niepełnosprawnością i jest on bliski uznanej w polskiej pedagogice specjalnej koncepcji wspólnych i swoistych cech rozwoju w sytuacji choroby przewlekłej Władysławy Pileckiej22.

Na schemacie (rys. 1) widoczne jest, że wśród potrzeb niespecyficznych dla niepełnosprawności wyróżniono zarówno potrzeby uniwersalne, warunkujące przetrwanie każdej jednostce, jak i rozwojowe, kluczowe w z punktu widzenia samorealizacji. Potrzeby specyficzne to takie, które wynikają bezpośrednio ze zmienionych sytuacją choroby/niepełnosprawności uwarunkowań i mają one charakter kompensacyjny. Nie ograniczają się jednak do działania "za" pacjenta, co określane jest jako system pielęgnacyjny w pełni kompensacyjny, choć i taka potrzeba może się ujawnić (np. oddychania "za" pacjenta przy użyciu respiratora czy odżywiania pozaustrojowego). System kompensacyjny stosuje się $\mathrm{w}$ wobec pacjentów niezdolnych lub o ograniczonej zdolności do wydawania sądów, opinii, do podejmowania świadomych decyzji samoopiekuńczych, dotyczy także opieki nad osobami z poważnie ograniczoną możliwością lub z niemożliwością poruszania się, komunikowania lub rozpoznawania zagrożeń ze strony środowiska ${ }^{23}$.

${ }^{22}$ W. Pilecka, Przewlekła choroba somatyczna w rozwoju dziecka, Kraków 2002, s. $17-18$.

${ }^{23}$ I. Płaszewska-Żywko, E. Wilczek-Rużyczka, Teoria pielęgnowania Dorothea' Orem, „Studia Medyczne” 2000, 26(2), s. 107-111. 
Choć sytuacja taka wydaje się specyficzna dla pielęgniarstwa, ma też swój odpowiednik w pedagogice. Analogia tego typu pielęgnacji kompensacyjnej dotyczy np. opieki nad dzieckiem z głęboką wielozakresową niepełnosprawnością, gdy działania opiekunów warunkują trwanie życia dziecka, często bez zapowiedzi lepszego jutra. Czasem nawet $\mathrm{z}$ perspektywą pogorszenia i śmierci, jak w przypadku genetycznych wad letalnych czy choroby terminalnej. Znaczenie pedagogiczne takich działań wyraża najlepiej pojęcie pielęgnacji wychowującej czy też wyodrębnienie się tanatopedagogiki jako szczególnej subdyscypliny pedagogicznej towarzyszącej $\mathrm{w}$ drodze do śmierci ${ }^{24}$. Nawet sytuacji pełnej pielęgnacyjnej kompensacji zaspokajania potrzeb można bowiem nadać sens pedagogiczny, wynikający z personalistycznego ujęcia osoby ludzkiej, nawet w najcięższej chorobie czy najgłębszej niepełnosprawności. Charakteryzuje je podmiotowe traktowanie osoby, a więc pielęgnowanie nie tylko jej, ale także samej relacji interpersonalnej, oraz zaspokajanie nie tylko ujawnianych, ale i domniemanych potrzeb przypisywanych (każdej) osobie. $Z$ zasady jesteś podmiotem, gdy inni traktuja cie jak podmiot, wywodzi się zalecenie, by być przy chorym - nawet, gdy on tego nie czuje; mówienia do niego - choć nawet tego nie słyszy; otaczania go pewnymi przedmiotami (książkami, obrazkami, zabawkami) - chociaż nawet $\mathrm{z}$ nich nie korzysta. Przy tym należy zaznaczyć, że tanatopedagogika nie jest pielęgnacją umierającego, ale tym wszystkim, co się dzieje w wymiarze relacyjnym, społecznym i duchowym, nawet wtedy, gdy pielęgnacja i walka o podtrzymanie życia wydają się dominować w działaniach wobec chorego.

W praktyce trudno wyznaczyć granicę, gdzie kończy się pielęgnacja kompensacyjna, a zaczyna pedagogiczna, jednak w modelu Orem jest nie tylko miejsce na działania edukacyjne, ale i tendencja, by przestrzeń tę sukcesywnie poszerzać, $\mathrm{w}$ miarę odzyskiwania zdolności samoopiekuńczych. Jest to więc model dynamiczny. Na rysunku 1. widać również, że zaspokajanie specyficznych potrzeb

${ }^{24}$ J. Binnebesel, Tanatopedagogika $w$ doświadczeniu wielowymiarowości człowieka i śmierci, Wydawnictwo Adam Marszałek, Torun 2010. 
związanych z chorobą stanowi rodzaj specjalistycznej interwencji medycznej o charakterze kompensacyjnym, częściowo kompensacyjnych lub edukacyjno-wspierającym w istniejących stanie kryzysu spowodowanego chorobą. Model Orem został tu zmodyfikowany o pętlę zwrotną, skierowaną ponownie w kierunku potrzeb uniwersalnych i rozwojowych, ukazując swoisty homeostatyczny i samowzmacniający się cykl sił witalnych i dążeń samorealizacyjnych, mierzonych aktualizacją różnych kategorii potrzeb. Jest to nieco inne ujęcie niż w jednym z najbardziej znanych, tradycyjnym, hierarchicznym modelu potrzeb Abrahama Maslowa - jego słynnej piramidzie, której nie przedstawiam z racji powszechnej znajomości tej teorii. Hierarchiczność potrzeb wyraża się tym, że potrzeby wyższego rzędu aktywują się dopiero po zaspokojeniu potrzeb z niższych poziomów. Mimo wielkiego wpływu tej teorii na współczesną naukę, zależność ta nie zawsze znajdowała potwierdzenie empiryczne, była przedmiotem krytyki oraz kolejnych przeobrażeń25. Zaproponowana na rysunku 1. modyfikacja modelu Orem łączy znaczenie potrzeb deficytu i potrzeb wzrostu - tych drugich lokalizowanych na wyższych pięter piramidy Maslowa - dla przywracania zdolności życia, funkcjonowania i samorealizacji, mimo istniejącej choroby czy niepełnosprawności. Można zatem koncepcję tę rozwinąć w celu ukazania roli zasobów osobistych w zjawisku rezyliencji czy potraumatycznego wzrostu, motywowanych potrzebami rozwojowymi.

\section{Potrzeba sensu życia oraz dystansu psychicznego we wzrastaniu (psychicznym) osób z niepełnosprawnością}

W polskiej literaturze psychologicznej i pedagogicznej znaczącą rolę odegrała monografia Kazimierza Obuchowskiego Psychologia dążeń ludzkich z 1983 r. Drugie wydanie tej książki ukazało się ze znamiennym metaforycznym tytułem dodatkowym Galaktyka po-

${ }^{25}$ D.T. Kenrick et al., Renovating the Pyramid of Needs: Contemporary Extensions Built Upon Ancient Foundations, "Perspect Psychol Sci." 2010 May, 5(3), s. 292-314. 
trzeb26. Metafora ta trafnie odzwierciedla wielość i złożoność potrzeb ludzkich oraz rolę, jaką odgrywają one w życiu człowieka. Autor, podobnie jak A. Maslow, wskazuje na pewną hierarchię potrzeb (można przyrównać tu przede wszystkim podstawę piramidy Maslowa i jej wierzchołek), jednak w kategoryzacji potrzeb posługuje się przede wszystkim ich aspektem treściowym. I tak K. Obuchowski wyróżnia potrzeby: fizjologiczne, seksualne, poznawcze, emocjonalne, potrzebę sensu życia oraz potrzebę dystansu psychicznego - określaną jako dojrzała potrzeba sensu życia27.

Ponieważ w praktyce wspierana osób z niepełnosprawnością koncentracja na potrzebach rozumianych jako deficyt zdominowała ujęcie rozwojowe, koncepcja Obuchowskiego stanowi inspirującą przeciwwagę, która może stanowić bazę wychowawczą i terapeutyczną dla problemów związanych z niepełnosprawnością i wzrostem (psychicznym, duchowym, osobistym), mimo tych problemów $^{28}$. Sens życia, sens istnienia, jako treściowy wyznacznik samorealizacji, wiąże się z aspektem aksjologicznym i teleologicznym wychowania. Jego odnajdowanie i definiowanie stanowi wyzwanie dla każdego człowieka, bez względu na istniejącą niepełnosprawność. Jednak w przypadku niepełnosprawności może stać się jeszcze nadrzędnym czynnikiem kompensującym istniejące ograniczenia. Jeszcze większe znaczenie dla osobistego wzrostu osób z niepełnosprawnością ma wzniesienie się ponad to, co indywidualne, bez zaprzeczania własnym doświadczeniom: dystans psychiczny do doświadczeń jednostkowych, przy jednoczesnej ich integracji, wydaje się wartościowym kierunkiem rozwoju i wychowania osób

${ }^{26}$ K. Obuchowski, Galaktyka potrzeb - psychologia dążeń ludzkich, Wydawnictwo Zysk i S-ka, Poznań 2000.

27 Ibidem.

${ }^{28}$ Fragmenty tej części zostały przedstawione w referacie Autorki pt. Niepetnosprawność w paradygmacie ludzkich potrzeb na Konferencji Niepetnosprawni w Państwie i Kościele. Potrzeby duchowe i społeczne osób niepetnosprawnych, Łódź 2010. Cały referat znajduje się w materiałach pokonferencyjnych pod red. S. Skobla, A Perzyńskiego i W. Kamińskiego, pod tym samym tytułem, Wydawnictwo Archidiecezjalne Wydawnictwo Łódzkie, Łódź. 
niepełnosprawnych, drogą do ich autonomii, intencjonalności i kontroli nad własnym życiem.

Realizacja potrzeby dystansu (ale nie izolacji od świata i nie dysocjacji od niechcianych, np. negatywnych doświadczeń!) daje szansę odróżnienia ja-przedmiotowego od ja-intencjonalnego. Niewiele niepełnosprawnych młodych osób dostaje w procesie wychowania ten prosty mentalny przepis na pozytywną asymilację negatywnych przeżyć, których nie są w stanie uniknąć. Tymczasem można powiedzieć, iż Obuchowski podaje gotową recepturę na poszukiwanie podmiotowego hard core własnej podmiotowości za pomocą techniki „schładzania" i uogólniania doświadczeń osobistych, poprzez nadawanie im rangi przedmiotu. Może to stanowić także wskazówkę terapeutyczną do pracy z osobami niepełnosprawnymi. Autor pisze:

Lęk, rozpacz, bycie chorym, bycie kaleką, radość i sukces, mogą występować $\mathrm{w}$ dwóch postaciach. W postaci tożsamej z osobą i w postaci właściwości osoby. (...) Gdy ja utożsamiam się z moim bólem lub $\mathrm{z}$ niepowodzeniem, one dla mnie są mną i dlatego ja nie mogę nimi kierować, nie mogę kontrolować ich. $\mathrm{W}$ istocie one kontrolują mnie ${ }^{29}$.

Dalej autor kontynuuje:

Może być jednak tak, że (np.) złość nie jest mną, ale jest moją złością, odczuwam ją, tyle, że jest ona we mnie, nie jest ona mną. Nadaję więc jej status przedmiotu, takiego samego jak moja ręka, komputer czy łyżka. Dlatego mogę tę złość kontrolowaćio ${ }^{30}$ Co więcej Człowiek odpowiednio nastawiony może kolejno poddawać swojej kontroli coraz więcej właściwości swego Ja. Nadając im status przedmiotu, wyłącza je ze swojego Ja, ze swojej podmiotowości, nadając im status przedmiotu ,ja-nie-ja" 31 .

Tak więc widzimy, jak subiektywna przebudowa poznawcza obiektywnej sytuacji, odbywająca się w ramach realizacji potrzeby dystansu, umożliwia kontrolę nad rzeczywistością - także ta trud-

\footnotetext{
${ }^{29}$ K. Obuchowski, op. cit., s. 326.

30 Ibidem.

31 Ibidem, s. 327.
} 
ną, nieprzyjazną, bolesną - i krystalizuje de facto pojęcie podmiotu. Model uprzedmiotowienia własnych negatywnych doświadczeń to także teoretyczne uzasadnienie dla nadania znaczenia - wydawać by się mogło mało istotnym - różnicom semantycznym w określeniach osoba niepełnosprawna (denotuje niepełnosprawność podmiotową) vs. osoba z niepełnosprawnością (denotuje niepełnosprawność uprzedmiotowioną, a więc nie sięgającą głębszych wymiarów człowieczeństwa i podmiotowości).

Ostatni fragment analizy wskazuje, jak w paradygmacie potrzeb ludzkich poszukiwać konkretnych strategii wspomagających rozwój i ograniczania negatywnych skutków niepełnosprawności. Potrzeby wyższego rzędu generują wzrost osobisty, gdyż mogą stanowić obszar zbierania doświadczeń, którym w procesie wychowania i samowychowania nadawany będzie sens: indywidualny sens jednostkowego życia, a dzięki osiąganiu dystansu - jego ponadindywidualny sens metafizyczny.

\section{Podsumowanie i konkluzja}

Pojęcie potrzeb i specjalnych potrzeb zdominowało obecnie dyskurs niepełnosprawności, jednak często używane bywa bezrefleksyjnie. Specjalne potrzeby (edukacyjne, rozwojowe) traktowane są często jako synonim niepełnosprawności, niestety coraz bardziej dysfemistyczny. W nazwach tych słowo "potrzeba" staje się przezroczyste, tzn. nie wyzwala refleksji na temat tego, czego faktycznie potrzebują określone tak osoby.

Niniejszy tekst miał na celu przywrócenie pojęciu potrzeby w odniesieniu do osób z niepełnosprawnością jej podstawowego, psychologicznego znaczenia oraz pedagogicznego, wychowawczego sensu. W szczególności wskazano kilka wybranych obszarów, w których pojęcie „potrzeby osób z niepełnosprawnością" nabiera szczególnego znaczenia teoretycznego oraz skłania do podejmowania działań praktycznych: diagnostycznych, wspierających, pielęgnacyjno-zdrowotnych, edukacyjno-wychowawczych. Ukazano pewne 
dylematy pojęciowe oraz wybrane ujęcia teoretyczne potrzeb - Orem, Maslowa, Obuchowskiego - odnosząc je do problemów pedagogiki specjalnej. Wydaje się, że szczególnie ujęcie potrzeby w kategorii czynnika wzrostu psychicznego może być użyteczne w wychowaniu, wspieraniu i terapii osób z niepełnosprawnością, co wykazano na przykładzie potrzeby sensu życia i potrzeby dystansu psychicznego.

Wydaje się, że współcześnie to nie tyle "specjalne potrzeby" (choć trudno kwestionować ich istnienie), co „niezaspokojone potrzeby” (i te specjalne, i te nie-specjalne), powinny wyznaczać charakter działań wspierających. „Specjalność” potrzeb jest sprzeczna z ideą inkluzji - specjalność nie mieści się w paradygmacie społeczeństwa dla wszystkich, co do czego jest już zgoda w odniesieniu do eliminowanego ze słownika pedagogiki specjalnej terminu "specjalna troska”. Natomiast niezaspokojenie potrzeb - zwłaszcza permanentne - jest silnym czynnikiem wykluczającym. Zatem to dążenie do skutecznego i racjonalnego zaspokajanie potrzeb jest faktyczną inkluzją, o ile jest działaniem na miarę rzeczywistych, spersonalizowanych potrzeb (ang. need-based service), a nie automatyzmem dopasowującym osoby $\mathrm{z}$ niepełnosprawnością do dostępnych usług. Stąd ogromnego znaczenia nabiera trafna diagnoza społeczna i indywidualna, ale także znajomość struktury oraz mechanizmów motywacyjnego i kompensacyjnego działania potrzeb osób z niepełnosprawnością. Przykładem racjonalnych działań może być opisane $\mathrm{w}$ artykule wsparcie w chorobie i niepełnosprawności wobec deficytu samoopieki oraz w odzyskiwaniu tej zdolności (koncepcja Dorothei Orem), jak również praca edukacyjno-wychowawczo-terapeutyczna nad zaspokojeniem potrzeby sensu życia osób z niepełnosprawnością oraz potrzeby dystansu psychicznego, określanej jako dojrzała potrzeba sensu życia (koncepcja Kazimerza Obuchowskiego).

\section{Bibliografia}

Barnes C., Sheldon A., 'Emancipatory' disability research and special educational needs, [in:] The Sage handbook of special education, red. L. Florian, Sage, London 2007, s. 233-246. 
Bigs A., Orem's Self-Care Deficit Nursing Theory: Update on the State of the Art and Science, "Nursing Science Quarterly", Vol. 21, Issue: 3, 2008, s. 200-206.

Binnebesel J., Tanatopedagogika w doświadczeniu wielowymiarowości człowieka i śmierci, Wydawnictwo Adam Marszałek, Toruń 2010.

Gernsbacher M.A., Raimond A.R., Balinghasay M.Th., Boston J.S., "Special needs" is an ineffective euphemism, "Cognitive Researche" No 1 (1): 29, 2016; https:/ / doi.org/10.1186/s41235-016-0025-4 [Pub. Online 2016 Dec 19], [dostęp: 15.01. 2018].

Harris J., Morgan H., Glendinning C. i in., Personalised social care for adults with disabilities: a problematic concept for frontline practice, "Health \& Social Care in the Community" 2006, 14, s. 125-135.

Kenrick D.T., Griskevicius V., Neuberg S.L., Schaller M., Renovating the Pyramid of Needs: Contemporary Extensions Built Upon Ancient Foundations, "Perspect Psychol Sci." 2010 May; 5(3), s. 292-314.

Kowalik G., Praktyczne zastosowanie modelu pielegnowania Dorothy Orem, "Studia Medyczne" 2012, 26(2), s. 107-111.

Luckasson R., Coulter D.L., Polloway E.A., Reiss S., Schalock R.L., Snell M.E. i in., Mental retardation: Definition, classification, and systems of supports (9th ed.). AAMR, Washington, DC 1992.

Noltemeyer A., Bush K., Patton J., Bergen D., The relationship among deficiency needs and growth needs: An empirical investigation of Maslow's theory, "Children and Youth Services Review", Vol. 34, Issue 9, September 2012, s. 1862-1867.

Obuchowski K., Galaktyka potrzeb - psychologia dążen ludzkich, Wydawnictwo Zysk i S-ka, Poznań 2000.

Orem D., Nursing: Concepts of practice, Mosby St. Louis, MO 2001.

Pilecka W., Przewlekła choroba somatyczna w rozwoju dziecka, Kraków 2002.

Płaszewska-Żywko I., Wilczek-Rużyczka E., Teoria pielęgnowania Dorothea' Orem, „Studia Medyczne” 2000, 26(2) s. 107-111.

Podgórska-Jachnik D., Praca socjalna z osobami z niepetnosprawnością $i$ ich rodzinami, Centrum Rozwoju Zasobów Ludzkich MPiPS, Warszawa 2014.

Pyżalski J., Podgórska-Jachnik D. (red.), Badanie potrzeb i satysfakcji z wybranych ustug skierowanych do rodzin z dziećmi z orzeczona niepetnosprawnościa w wieku 8-16 lat. Raport z badań Instytutu Medycyny Pracy na zlecenie Regionalnego Centrum Polityki Społecznej w Łodzi 2016, [online] http:/ / www.imp.lodz.pl/upload/aktualnosci/2016/raport.pdf [dostęp: 5.01.2018].

Rathus S.C., Psychologia wspótczesna, Wydawnictwo GWP, Gdańsk 2005.

Sochańska-Kawiecka M. i wsp., Badanie potrzeb osób niepetnosprawnych - RAPORT KOŃCOWY; Badania Społeczne MSK, PFRON 2017, [online] https://www.pfron. org.pl/fileadmin/Badania_i_analizy/Badanie_potrzeb_ON/Raport_koncowy_ badanie_potrzeb_ON.pdf [dostęp: 5.01.2018]. 
The Warnock Report, Special Educational Needs. Report of the Committee of Enquiry into the Education of Handicapped Children and Young People, Her Majesty's Stationery Office, London 1978.

\section{Netografia}

http:/ / portalwiedzy.onet.pl/tlumacz.html?qs=need\&tr=ang-auto\&x=35\&y=8 [dostęp: 18.05.2018].

http://www.slownik-online.pl/kopalinski/6912E60D67C51EA4412565BA002919B3.php [dostęp: 18.05.2018]. 